\title{
SPREAD OF PRUNE DWARF AND PRUNUS NECROTIC RINGSPOT VIRUSES IN GOLDEN QUEEN PEACH IN HAWKE'S BAY AND EFFECT ON FRUIT YIELDS
}

\author{
P.N. WOOD, K.G. TATE ${ }^{1}$, D.W. MANKTELOW, \\ J. MORTON ${ }^{2}$ and A.J. KALE ${ }^{3}$ \\ HortResearch, Hawke's Bay Research Centre, Private Bag 1401, Havelock North \\ ${ }^{1}$ Crop Health Services, PO Box 2153, Stortford Lodge, Hastings \\ ${ }^{2}$ Rex Graham \& Associates Ltd., PO Box 446, Hastings \\ ${ }^{3} \mathrm{~J}$ Wattie Foods Ltd, PO Box 439, Hastings
}

\begin{abstract}
Two Golden Queen peach blocks, one propagated from virus-free scions (Block A), the other from non-indexed sources (Block B), were ELISA-tested 5-7 years after planting for prune dwarf virus (PDV) and prunus necrotic ringspot virus (PNRSV). Trees in Block A were 18\% infected by PNRSV at year 5 and $60 \%$ by year 7 , at which time $1 \%$ also had PDV. Block B was $100 \%$ infected by PNRSV and $9 \%$ with PDV by year 5 , increasing to $15 \%$ by year 7 . Between years 5 and 7 , salable yield reduced by $18 \%$ as a result of PNRSV-infection. Dual infection was likely to have reduced average salable yield by $32 \%(9.6 \mathrm{t} / \mathrm{ha})$ and gross returns by $\$ 4,805 /$ ha.
\end{abstract}

Keywords: peach, prune dwarf virus, prunus necrotic ringspot virus, peach rosette, ELISA

\section{INTRODUCTION}

Prunus necrotic ringspot virus (PNRSV) and prune dwarf virus (PDV) in New Zealand were first reported by Fry and Wood (1971), their widespread occurrence in Golden Queen peach trees was reported by Wood (1979a). PNRSV is relatively symptomless in New Zealand stonefruit (Wood 1979b). Peach rosette (PR) describes the symptoms produced by dual infection of both viruses, where infected branches develop shortened internodes and rosetting of foliage, gradually leading to severe stunting and decline. Both viruses are pollen transmitted and bees can spread these viruses rapidly within and between peach blocks. Wood (1979a) first reported declining yields as a result of PNRSV infection and this led to the establishment of a government-funded virus-free planting scheme for the Golden Queen peach industry in Hawke's Bay. This scheme, based on indicator plant indexing, was abandoned on grounds of cost when 'user-pays' was introduced by the government in 1986. However the availability of ELISA kits a few years later enabled lower cost virus-indexing and the ability for the first time to test large numbers of trees cheaply and rapidly. Pine (1964) in California, and Smith and Challen (1977) in Victoria, had measured the dramatic effects of dual virus infection on yield but this had not been done in New Zealand. This paper presents the results of three years of ELISA indexing of two Golden Queen peach blocks in Hawke's Bay for PNRSV and PDV and records the effects of both viruses on growth and yield.

\section{METHODS}

Two, five-year-old (1991-92 season) Golden Queen peach blocks near Hastings, about $400 \mathrm{~m}$ apart were selected as the sites for this study. One (Block A) was planted with trees propagated from virus-free scions and the other (Block B) from non-indexed material (likely to be virus-infected). During November to 20-December 1991, 1992 and 1993, all trees from both blocks were sampled by randomly pinching off five shoot tips (several unfolding leaflets) from terminals around each tree. These were placed in plastic 
bags in a chilly bin and virus tested by ELISA within 24 hours of sampling. To avoid possible contamination, hands were washed between tree samples.

ELISA kits T987 and T305 (Agdia Inc., 30380 County Rd Elkhart, IN., USA) were used to test for PNRSV and PDV respectively. Substrate colour changes were visually assessed in comparison with known controls. Selected trees were resampled up to 10 days later and confirmation-tested for PNRSV in 1992 at MAF's Lynfield Diagnostic Station and in 1993 at HortResearch Mt. Albert Research Centre, using cucumber seedling indicator plants.

Yield and growth parameters were recorded each year from 10 replicate trees for each of the following virus infection/block combinations: Block A, uninfected and PNRSV-infected trees at 5.4 x 4.9 m spacings; Block B, PNRSV-infected, PNRSV + PDV-infected (PR latent) and PNRSV + PDV-infected (PR visual) at $6.1 \times 6.1 \mathrm{~m}$ spacings.

Each year, trees were individually harvested at maturity and yield data and butt circumferences ( $20 \mathrm{~cm}$ above ground) were recorded. The data were analyzed to obtain various yield parameters (see Table 3 ) and gross returns calculated based on the current prices for process grades. Data were statistically analyzed using ANOVA. Betweenblock statistical comparisons were not made due to different tree spacings and orchard management practices. Where trees in the yield and growth study blocks became infected with a new virus, silver leaf or blast, they were replaced with trees of the same virus status to maintain ten replicates in each category. After the first season, it was learned that Block B trees were of two ages (see Table 2), which added a confounding factor to the comparison.

\section{Incidence and spread of PNRSV and PDV}

\section{RESULTS AND DISCUSSION}

In Block A (initially virus-free), $82 \%$ of trees remained healthy (free of PNRSV and PDV) after five years but only $39 \%$ were healthy by year 7 , indicating that virus introduction into the block had been relatively slow in years 1-5 but rapid after year 6 (Table 1). By year 7, 60\% of the trees were PNRSV-infected and 1\% PDV-infected. It was observed that most infected trees in Block A were on the side closest to Block B (400 m away), consistent with observations from earlier work which indicated that bees were the most likely vector (Wood 1979b; Uyemoto et al. 1992). By contrast Block B had no healthy trees at year 5, with 100\% PNRSV-infected and 9\% PDV-infected, increasing to $15 \%$ PDV-infected at year 7 .

ELISA tests of Block B indicated a change in virus status of 11 trees from PDVpositive in 1991 to negative in 1992. In 1993 most of these trees again indexed positive. This was most likely due to an uneven distribution of PDV in the trees. In 1992 there was close agreement between ELISA and indicator plant tests for plants that were PNRSV negative. That, ELISA detected more PNRSV positive plants could be a result of the test being more sensitive. However, the correlation between the two test methods was poor in 1993. Only $18 \%$ of ELISA-positives and $29 \%$ of ELISA-negatives were confirmed by indicator plant tests (Table 1). While some disagreement between ELISA and indicator tests can be expected (D. Elliott pers. comm.), the level of disagreement found was unacceptably high. The main reasons suggested for this are: 1) an uneven distribution of virus in newly infected trees i.e. in 1993, ELISA detected a large increase in diseased trees; 2) samples for confirmation-tests taken too late in season and virus titre may have fallen due to higher growing temperatures; 3) a loss of virus titre during transit to Auckland. The first two factors could explain how the inconsistency between virus detection methods was worse in 1993 than in 1992.

The ELISA results were considered to be a more reliable indication of virus spread for several reasons: 1 ) the yearly pattern of virus increase was similar to that in a comparable study by Uyemoto et al. (1992); 2) the location of infected trees within the two blocks followed expected patterns and produced yield effects which correlated with the virus status indicated determined by ELISA tests; 3) ELISA PDV test results were in agreement with those trees expressing PDV + PNRSV symptoms in the orchard.

TABLE 1: Results of ELISA and indicator-plant tests for prunus necrotic 
ringspot virus (PNRSV) and prune dwarf virus (PDV) monitoring in Golden Queen peach trees.

\begin{tabular}{lcccccc}
\hline Number of: & 1991 & $(\%)$ & 1992 & $(\%)$ & 1993 & $(\%)$ \\
\hline Block A & & & & & & \\
trees ELISA tested & 192 & - & 192 & - & 192 & - \\
healthy trees & 158 & $(82)$ & 149 & $(77)$ & 76 & $(39)$ \\
PNRSV +ve & 34 & $(18)$ & 43 & $(22)$ & 116 & $(60)$ \\
PNRSV + PDV (PR) +ve & 0 & $(0)$ & 1 & $(0.5)$ & 2 & $(1)$ \\
& & & & & & \\
Block B & & & & & & \\
trees ELISA tested & 198 & - & 198 & - & 222 & - \\
healthy trees & 0 & $(0)$ & 0 & $(0)$ & 0 & $(0)$ \\
PNRSV +ve & 198 & $(100)$ & 198 & $(100)$ & 222 & $(100)$ \\
PNRSV + PDV (PR) +ve & 18 & $(9)$ & 16 & $(8)$ & 33 & $(15)$ \\
Initially PR +ve, now PR -ve & - & - & 11 & $(6)$ & 5 & $(2)$ \\
newly PR +ve trees & - & - & 9 & $(5)$ & 22 & $(10)$ \\
& & & & & & \\
Confirmation tests & & & & & & \\
treesindicator-plant tested & 0 & - & 92 & - & 100 & - \\
totalELISA-tests confirmed & - & - & 80 & $(87)$ & 22 & $(22)$ \\
PNRSV +ves confirmed & - & - & $11 / 22$ & $(50)$ & $12 / 66$ & $(18)$ \\
PNRSV -ves confirmed & - & - & $69 / 70$ & $(99)$ & $10 / 34$ & $(29)$ \\
\hline
\end{tabular}

${ }^{1}+\mathrm{ve}(\mathrm{s})=\operatorname{positive}(\mathrm{s}) ;-\mathrm{ve}(\mathrm{s})=\operatorname{negative}(\mathrm{s})$

\section{Effect of virus severity on yield and tree size}

A difference in PNRSV-infected tree size between Blocks A and B was still apparent at year 7 because 4 trees in Block B were 1 year older (and consequently larger) than those in Block A (Table 2). This age difference together with management and spacing variations meant that trees of similar virus status in each block could have different yields. Also, because trees with higher virus severities were mostly 1 year older than those with lower virus severities, actual yield effects could be higher than those recorded.

TABLE 2: Yield and size of trees with different virus status in 1993.

\begin{tabular}{|c|c|c|c|c|c|c|c|c|}
\hline \multirow[b]{2}{*}{ Block } & \multirow{2}{*}{$\begin{array}{l}\text { Virus } \\
\text { Status }^{1}\end{array}$} & \multicolumn{2}{|c|}{ Yield (t/ha) } & \multirow{2}{*}{$\begin{array}{l}\text { Total fruit } \\
\text { (No./ha) }\end{array}$} & \multicolumn{2}{|c|}{$\begin{array}{l}\text { Butt. circumf. } \\
(\mathrm{cm})\end{array}$} & \multicolumn{2}{|c|}{$\begin{array}{c}\text { Tree age } \\
\text { in } 1993 \text { (Nos) }\end{array}$} \\
\hline & & Total & Salable & & Blocks & Mean & $7 \mathrm{yr}$ & $8 y r$ \\
\hline A & Healthy & $49.5 \mathrm{a}^{2}$ & $37.7 \mathrm{a}$ & $408,942 \mathrm{a}$ & $52.6 \mathrm{a}$ & 52.0 & 10 & 0 \\
\hline A & PNRSV & $40.2 \mathrm{~b}$ & $30.7 \mathrm{~b}$ & $325,046 \mathrm{~b}$ & $51.4 \mathrm{a}$ & & 10 & 0 \\
\hline B & PNRSV & $48.8 \mathrm{a}$ & $28.7 \mathrm{a}$ & $466,729 \mathrm{a}$ & $56.7 \mathrm{a}$ & 53.2 & 6 & 4 \\
\hline B & PR-latent & $35.9 \mathrm{~b}$ & $23.9 \mathrm{a}$ & $326,821 \mathrm{~b}$ & $50.3 \mathrm{c}$ & & 3 & 7 \\
\hline B & PR-visual & $40.7 \mathrm{ab}$ & $22.2 \mathrm{a}$ & $405,321 \mathrm{ab}$ & $52.6 \mathrm{~b}$ & & 2 & 8 \\
\hline
\end{tabular}

${ }^{1} \mathrm{PNRSV}=$ prunus necrotic ringspot virus, $\mathrm{PR}$ (peach rosette $)=$ combined prune dwarf virus + PNRSV infection

${ }^{2}$ For all tables, different letters within the same block and column indicate statistical significance, $(\mathrm{P}<0.05)$.

In Block A in year 7, healthy trees produced more total fruit than infected trees and PNRSV reduced salable yields by 7 t/ha (19\%) without significantly affecting butt 
circumference. This compared with a reduction of $8 \mathrm{t} / \mathrm{ha}$ in year 6 and $1.4 \mathrm{t} / \mathrm{ha}$ reduction in year 5. In Block B in year 7, additional infection by PDV further reduced total fruit numbers and salable yields by $6.5 \mathrm{t} / \mathrm{ha}(23 \%)$. This occurred within 7 years of planting, and differences would probably have been greater had all trees been the same age. Significantly smaller butt circumferences were recorded in PR-infected trees.

The yield depressions recorded here exceed those recorded by Pine (1964) in the USA and by Smith and Challen (1977) in Australia, where yield reductions of about $32 \%$ occurred from dual infection with PDV and PNRSV. Uyemoto et al. (1992) reported $30 \%$ yield and $23 \%$ trunk girth reductions respectively over a four year period in California. Their study also showed an increase in dual infection from 0 to $72 \%$ in one block and demonstrated that bees carried infected pollen.

Effect of virus severity on fruit quality

In Block A in year 7, healthy trees produced more undersized fruit but less split, decayed or dropped fruit than did virus-infected trees (Table 3). This confirmed trends apparent in years 5 and 6 and grower observations that virus infection increased fruit splitting, which had the effect of increasing the incidence of brown-rot-infected and dropped fruit.

TABLE 3: Percentage of fruit in size $\operatorname{classes}^{1}$ from trees with different virus status in year 7 (March 1994).

\begin{tabular}{|c|c|c|c|c|c|c|c|}
\hline Block & $\begin{array}{l}\text { Virus } \\
\text { Status }^{2}\end{array}$ & Grade 1 & Grade 2 & Undersized & Split & $\begin{array}{l}\text { Brown } \\
\text { rot }\end{array}$ & Dropped \\
\hline A & Healthy & $19.0 \mathrm{a}$ & $47.0 \mathrm{a}$ & $20.3 \mathrm{a}$ & $1.9 \mathrm{~b}$ & $2.5 \mathrm{~b}$ & $9.2 \mathrm{~b}$ \\
\hline A & PNRSV & $25.3 \mathrm{a}$ & $39.1 \mathrm{a}$ & $14.1 \mathrm{~b}$ & $3.6 \mathrm{a}$ & $4.8 \mathrm{a}$ & $13.2 \mathrm{a}$ \\
\hline B & PNRSV & $10.2 \mathrm{ab}$ & $36.7 \mathrm{a}$ & $32.8 \mathrm{a}$ & $3.9 \mathrm{a}$ & $4.5 \mathrm{a}$ & $11.9 \mathrm{a}$ \\
\hline B & PR-latent & $15.5 \mathrm{a}$ & $38.3 \mathrm{a}$ & $24.8 \mathrm{a}$ & $3.2 \mathrm{a}$ & $3.5 \mathrm{ab}$ & $14.6 \mathrm{a}$ \\
\hline B & PR-visual & $5.6 \mathrm{~b}$ & $36.1 \mathrm{a}$ & $41.7 \mathrm{a}$ & $2.9 \mathrm{a}$ & $2.9 \mathrm{~b}$ & $10.8 \mathrm{a}$ \\
\hline
\end{tabular}

${ }^{1}$ Grade 1, fruit weighing over $151 \mathrm{~g}$; Grade 2, fruit weighing 108-151 g; undersized, fruit weighing < $108 \mathrm{~g}$; split, split fruit not including those with brown rot or dropped; brown rot, fruit with brown rot but not dropped; dropped, all naturally fallen fruit including some with brown rot or splitting.

${ }^{2} \mathrm{PNRSV}=$ prunus necrotic ringspot virus, $\mathrm{PR}$ (peach rosette $)=$ combined prune dwarf virus + PNRSV infection

In Block B in year 7, Grade 1 fruit numbers in PR-visual trees were significantly lower than in PR-latent trees. This confirmed a trend observed in year 5 but not in year 6 . Over the three years there was no consistent pattern in effect of virus intensity on percentage of fruit in each grade.

On average over the three years of this study, PNRSV infected trees yielded $18.5 \%$ less than healthy trees (Block A, Table 4) and trees with visually apparent PR symptoms yielded 19\% less than trees with PNRSV (Block B, Table 4). Since PNRSV infected trees at both blocks produced similar mean yields and gross returns, it was possible to compare the PR infected trees with the performance of healthy trees in Block A. Under this comparison, over years 5-7, trees with visible PR symptoms yielded $9.6 \mathrm{t} / \mathrm{ha} \mathrm{(32 \% )}$ or $\$ 4,800 /$ ha less on average per year than healthy trees. The real loss in potential yield between years 5-10 may actually be higher than this estimate, due to virus infection reducing tree growth and hence potential for yield increase with increasing tree size. Effect of virus severity on gross returns

TABLE 4: Salable yield and gross returns for the 1991-92, 1992-93 and 199394 seasons. 


\begin{tabular}{llrcccc}
\hline & & \multicolumn{5}{c}{ Salable yield(t/ha) } \\
Block & $\begin{array}{l}\text { Virus } \\
\text { status }\end{array}$ & 1992 & 1993 & 1994 & Mean & Mean \\
& & & & & \\
\hline loss
\end{tabular}

${ }^{1}$ PNRSV, prunus necrotic ringspot virus; PR (peach rosette), combined prune dwarf virus + PNRSV infection

${ }^{2}$ Corrected for tree age and assuming a return of $\$ 560 / \mathrm{t}$ for Grade 1 and $\$ 375 / \mathrm{t}$ for Grade 2

\section{CONCLUSION}

This study demonstrated that initially virus-free plantings can become $60 \%$ infected by year 7 if diseased plantings are nearby, while non-indexed trees, if not already $100 \%$ infected by PNRSV, are probably infected very early in their productive life without necessarily showing obvious symptoms. PNRSV alone can reduce salable yields and gross returns by around $18 \%$. The combined effect of both PNRSV and PDV is likely to be a $32 \%$ reduction in both average salable yield and gross returns $(9.6 \mathrm{t} / \mathrm{ha}$ and $\$ 4805$ /ha respectively) per year. Thus, orchards planted in non-indexed trees are likely to become uneconomic relatively early in their life. By contrast, orchards established from clean stock are more likely to produce normally until year 5 and potentially for considerably longer if from infected trees.

Re-establishment of a virus-free planting scheme in Hawke's Bay is urgently required and has been initiated on the basis of these results. While virus-free plantings can be expected to remain virus-free for only 5-7 years, this is much better than the present use of non-indexed planting material. Significant increases in yields and gross returns are possible. However, if clean trees are planted within bee foraging range of diseased trees, the potential gains will be short-lived. A coordinated district approach is required.

The lack of agreement between ELISA and indicator plant tests in our study requires further work to confirm the cause(s) of the discrepancy and increase confidence in ELISA screening of the large numbers of trees required in a clean stock program.

\section{ACKNOWLEDGEMENTS}

Sincere thanks are expressed to Laurie Cooke and Doug and Lynne Hill for use of Golden Queen Blocks for this study; to Dale Fuller and Lynnette Blackburn for ELISA testing; to Dave Elliott, MAF Quality Management, Lynfield, and Garry Wood, HortResearch, Auckland, for indicator plant tests; and to Dianna Winfield for expert technical assistance. This research was funded by J. Wattie Foods Ltd.

\section{REFERENCES}

Fry, P.R. and Wood, G.A., 1971. Prunus necrotic ringspot virus and prune dwarf viruses 
in New Zealand. N.Z. J. Agric.Res. 14: 515-525.

Pine, T.S., 1964. Influence of necrotic ringspot virus on growth and yield of peach trees. Phytopath.54: 604-605

Smith, P.R. and Challen, D.K., 1977. Initial and subsequent yield reduction of peach trees affected by peach rosette and decline disease.Aust. J. Exp. Agric. Animal Husb. 17: 174-176.

Uyemoto, J.K., Asai, W. K. and Luhn, C.F., 1992. Ilarviruses: evidence for rapid spread and effects on vegetative growth and fruit yields of peach trees. Plant Dis. 76: 7176.

Wood, G.A., 1979a. Virus and virus-like diseases of pome fruits and stone fruit in New Zealand. DSIR Bulletin 226: 34-40.

Wood, G.A., 1979b. Prunus necrotic ringspot virus and it's occurrence in NZ stone-fruit trees. The Orchardist of N.Z., Feb 1979: 25-26. 